\title{
LEARNING FUNCTIONAL GRAMMAR IN ESP CLASS
}

\author{
Dian Arsitades Wiranegara \\ (dwiranegara@gmail.com)
}

Pusat Pengembangan Bahasa Inggris

Universitas Islam Negeri Maulana Malik Ibrabim Malang

\begin{tabular}{|c|c|}
\hline ARTICLE & ABSTRACT \\
\hline $\begin{array}{l}\text { Keywords: } \\
\text { language, } \\
\text { context, text, \& } \\
\text { English for } \\
\text { specific } \\
\text { purposes. }\end{array}$ & $\begin{array}{l}\text { Learning functional grammar for ESP class is aimed to improve students } \\
\text { of non-English language department to understand how English works } \\
\text { effectively, appropriately, and accurately. Teaching ESP cannot be } \\
\text { separated by the use or the implementation of functional grammar as it is } \\
\text { clear that teaching English as a foreign language in ESP class is also } \\
\text { concerned with the language as an instrument of social interaction rather } \\
\text { than as a system which is viewed in isolation. Teaching functional } \\
\text { grammar for ESP students, in this matter, students of non-English } \\
\text { language department, can result such a hard working effort for teachers in } \\
\text { order to help them understand the-so-called functional grammar. As a } \\
\text { matter of fact, ESP can combine subject matter of the related field of } \\
\text { study and English language teaching. Therefore, learning functional } \\
\text { grammar has actually been conducted in ESP class since the students are } \\
\text { also involved with the use of their background knowledge of the field of } \\
\text { study. }\end{array}$ \\
\hline
\end{tabular}

\section{INTRODUCTION}

The basic idea of introducing functional grammar for ESP class has come from the workshop presented by Prof. Emi Emilia of Indonesia University of Education UPI Bandung, in May 2014 at PPBI Uin Maliki Malang. The workshop has resulted that teaching English for ESP class cannot be separated by the use or the implementation of functional grammar as it is clear that teaching English as a foreign language in ESP class is also concerned with the language as an instrument of social interaction rather than as a system which is viewed in isolation. Language informs the way people think, experience, and interact with each other. As (Thompson, 2003: 37) refers to any system of communication. Language is understood in its relationship to social structure (Halliday, 1985, p.3). Jones \& Lock (2011: 1-2) have further explained that people speak or write in meaningful units called texts, which consist of stretches of language that 'hang together' in some way. 
JEASP

Journal of English for Academic and Spesific Purposes

Volume 1 Number 1, June, 2018

Furthermore, texts are always produced in some kind of context. As features of context change, texts change.

Structure refers to a sequence of linguistic units that are in a certain relationship to one another (Platt et al, 1992, p.358). It describes the structure of a language and the way in which its units such as words and phrases are combined to produce sentences in the language. Emilia (2014, p.19) has further stated that grammar is something to attract the attention of variety of people in the communityteachers, parents, academics, politicians, news presenters, writers to the editor, ect. Derewianka (1998, p.1 as cited in Emilia, 2014, p.19) Grammar is defined as a way of describing how language works to produce meaning in a particular culture. Hence, grammar is the key to language teaching. This also involves the knowledge of the language since it looks at language in relation to how it is structured in the speaker's mind. It considers the meanings and functions of sentences have in the overall system of language.

\section{THE NATURE OF READING TEXT}

Burns et al. (1996:5) define reading as a highly complex act that consists of two major components: a process and a product. Reading does not only involve the skills in understanding the written texts but also the relationship between the scripts. Reading may be described in many ways by different experts. However, there are points of general agreement among reading experts. One point is that comprehension is the purpose of reading. Thus, reading can be concluded as an activity that aims primarily at understanding or constructing meaning from the written texts. Learners can get many benefits by reading written materials due to the importance of reading that has three aspects such as every aspect of live involves reading, reading is enjoyment, and reading means an activity to obtain information (Burns et al.,1996:6).

Realizing the importance of reading ability in the present time, it is a must that students should have avid reading as reading will lead them to obtain so many kinds of information and knowledge. Somehow, the students should also be motivated to understand that in the process of reading there is a communication 
JEASP

Journal of English for Academic and Spesific Purposes

Volume 1 Number 1, June, 2018

between a writer and reader. In this activity, reading deals with decoding and the comprehension process in which a reader tries to understand what a writer has put in a text. In the activity, the reader actively has to relate his or her prior knowledge or schemata to comprehend the text better.

Grammar itself is a complex system (Emilia, 2014, p.19). However, it still can be taught to students of ESP class whose knowledge come from different background. Feez \& Joyce (2000, p.5 as cited in Emilia, 2014, p.20) Grammar can make system of patterns is used to select and combined words. Therefore, grammar can make to express people, or in this context, is used to express students ideas, thoughts and, of course, feelings. Halliday (1985, p.5; Halliday 2002; Halliday \& Matthiessen 2004; Martin \& Rose 2003, 2008; Christie 2005, 2012 cited in Emilia, 2014, p.25) Language is treat as a resource of meaning. This can be viewed that the three elements that are language, context, and text are intertwined in order to reflect the way into undersranding about language lies in the study of texts.

\section{TEXT AND CONTEXT}

Text is the basic unit of meaing. Therefore, text shaped in language is not communicated in isolation or idealised extracts. Language (Emilia, 2014) The term context can help to understand the particular meaning of the word, phrase, etc. For example, the word loud in loud music can refer to "noisy". All language occurs in social contexts. As a result, context is defined as a context of situation means the environment of the text. Malinowski (1923, 1935 cited in Halliday \& Hasan, 1985, p.5) known as closely related sense that is used for the term context. These situations (Halliday \& Hasan, 1985, p.12) cover the field of discourse that refers to what is happening to the nature of social action. The tenor refers to who is taking part to the nature of the participants, people's statuses and roles, what kind of relationship takes part in the conversation. Finally, the mode refers ro to what part the language is taking part or playing. It deals with what it is the participants are expecting the language to do for them in the situation. This can be how it is used by oral or written, or rather channel. While the text as Halliday (1985, p.10) states that is something treated as meaning. Text is a semantic unit as to its nature that when it is 
JEASP

Journal of English for Academic and Spesific Purposes

Volume 1 Number 1, June, 2018

written down it looks as though it is made of words and sentences, it is made of meaning. However, this is understood in a broader sense that everything that gives understandable meaning is text, including things in the world. Text can be resulted as the product and process. The product of meaning as well as the process of creating meaning. Text is seen as the product of communication. Conversation produces text and so does a person writes. Therefore, text can cover both of these activities. This can be also said that language is a socio-semiotic perspective as it is known for the study of signs pioneered by Saussure's ideas as a result of language is a social system (Halliday \& Hasan, 1985, p.12).

These elemets: language, context and text can help and form grammar as it is the key of language, key of meaning and it also helps how language work. By learning grammar, as Derewianka (1998, p.1 cited in Emilia, 2014, p. 26) can help students to reflect on how the English language works, help shared language for talking about the main features, understand how its structures create different kinds of meaning, examine patterns of language and words choices to critically analyse texts, and can help to use language effectively, appropriately, and accurately. Hence for educational purposes, especially in relation to ESP learning, learning functional grammar can enhance students' ability to learn language through specific context. ESP is concentrated more in context than on teaching grammar and structure; however, its purposes is that English is not taught as a subject separated from the students' real world (or wishes); instead, it is integrated into a subject matter area important to the learners (Fiorito, 2005).

ESP or English for Specific Purposes is focused on specific needs of adult learners to be used in their specific fields, such as law, economics, science and academic learning (Dudley-Evans, 2001). The specific refers to the specific purposes of learning English. It will equip the learners with intermediate level of competence of using English in particular field of knowledge. Hence, the material of grammar of English language teaching is designed specifically in accordance with their field subject as English is needed by a particular group of learners or learners of specialist domain. 
JEASP

Journal of English for Academic and Spesific Purposes

Volume 1 Number 1, June, 2018

Teaching functional grammar for ESP students, in this matter, students of non-English language department, can result such a hard working effort for teachers in order to help them understand the-so-called functional grammar. However, as a matter of fact, ESP can combine subject matter of the related field of study and English language teaching. The combination can be conducted and taught because students can apply what they learn in their English classes to their main field of study, from accounting, business management, economics, computer science to tourism, etc. Students can also use the vocabulary and structures that they learn in a meaningful context as they experience in the real world, or rather the context of each field of study. For this reason, context and text of language are intertwined with the subject matter of ESP. Hence, learning functional grammar has actually been conducted in ESP class since the students are also involved with the use of their background knowledge of the field of study.

\section{FUNCTION AS A FUNDAMENTAL PRINCIPLE OF LANGUAGE}

The concept of function (Halliday \& Hasan, 1985: 17) is synonymous with that of use. Function is interpreted not just as the use of language but as a fundamental property of language itself, something that is basic to the evolution of the semantic system. This amounts to saying that the organisation of every natural language is to be explained in terms of a functional theory. Therefore, this has led to the experiential meaning where the sentence as expression of meanings of different kinds. Experiential meaning represents the real world as it is apprehended in human experience.

The meaning of this function — fundamental principle of language-involves the point of view of its function in the process of social interaction (Halliday \& Hasan, 1985: 20). It is interpreted as a way of reflecting a reality. Henceforth, this can be interpreted by using the terminology as language reflection and language as action as another way of referring to experiential and interpersonal meaning. 
JEASP

Journal of English for Academic and Spesific Purposes

Volume 1 Number 1, June, 2018

\section{TRANSITIVITY SYSTEM}

Transitivity system belongs to the experiential metafunction and is the overall grammatical resource for understanding the meaning (Martin, Matthiessen \& Painter, 1997, p.100) in (Emilia, 2014: 149). It deals with the content expressed in language: all the doing, sensing, being, saying activities that happen in the world. Transitivity system can refer to a system for describing the whole clause, rather than just the verb and its object.

Transitivity system can be meant (Emilia, 2014: 150) as understanding six different types of process of manageable set in English language. They include material, mental, verbal relatonal, behavioral and exixtential. Each process, Halliday (1994a: 107 in Emilia, 2014: 150) consists, in principle of three components: the process, participants and circumtances. Below is the description of the process.

\begin{tabular}{cccc}
\hline participant & Process & participant & Circumtances \\
\hline Many students & Wear & uniforms & To school \\
\hline
\end{tabular}

(source: Emilia, 2014: 150)

The above can be described that the process is expressed in a verb, while the participants, of course, in noun or noun groups and the circumtances are expressed in a prepositional phrase; however they can be expressed in adverbial expressions.

Material process can be said as process of doing (Halliday, 1994a: 110 in Emilia, 2014: 151). Material processes are expressed physically done something or which is done to some other entity (Gerot \& Wignell, 1994: 55). Material process deals with the Actor as the sole participant (in a clause with a Process that is expressed in transitive verb) as it is shown below by Emilia $(2014,151)$.

\begin{tabular}{cccc}
\hline The Merapi & Erupted & In Yogyakarta & last year \\
\hline Actor & Process: Material & Circumtance: & Cir: Loc: Time \\
& & Location: Place & \\
& & \\
\hline
\end{tabular}

Material process with an Actor and a Goal (active) (a Process expressed in a transitive verb) 
JEASP

1FaSP Journal of English for Academic and Spesific Purposes Volume 1 Number 1, June, 2018

\begin{tabular}{cccc}
\hline Dian & Prepared & his thesis & for a year \\
\hline Actor & Process: material & goal & Circumstance: Loc: \\
& & & time
\end{tabular}

Material processes with a goal can be realised in an expression that uses an agentless passive (But, et al, 2000: 53 in Emilia, 2014: 152)

\begin{tabular}{ccc}
\hline This book & was written & in Australia \\
\hline Goal & Process: Material & Circumstance: Loc: Place \\
\hline
\end{tabular}

Material Processes with a range and a Beneficiary:

\begin{tabular}{cccc}
\hline Her husband & has never done & anything & for her \\
\hline Actor & Process: material & range & Beneficiary \\
\hline
\end{tabular}

By considering Range in particular, Halliday (1994a in Emilia, 2014: 152) suggests that a range may be an entity that exists independently of the process, however, this also indicates the domain over the process happens. In English expression, a range may occur in: have a bath, make mistakes, do a little dance, take a quick look, give her usual welcoming smile (Halliday, 199a: 147). Material processes can be expressed in transitive verbs with a goal or intransitive verb without a goal Fairclough (2003: 142) as this example below.

\begin{tabular}{ll}
\hline The president & resigned \\
\hline Actor & Process: material \\
\hline
\end{tabular}

\begin{tabular}{l} 
The managing director $\quad$ dismissed \\
\hline Actor \\
\hline Mental processes (sensing verbs) refers to meanings of thinking or feeeling \\
(Eggin, 1994: 240 in Emilia, 2014: 153 ). Sensing processes can be understood as \\
people internal world and they are typically used in relation to humans or non- \\
humans given human-like qualities, in describing what humans think, feel, desire,
\end{tabular}


perceive (Derewianka, 2011: 22). These sensing processes can be shown below by Derewianka, (2011: 22 in Emilia, 2014: 153).

\begin{tabular}{llll}
\hline \multicolumn{1}{c}{ Cognition (thinking) } & \multicolumn{1}{c}{$\begin{array}{c}\text { Feeling and } \\
\text { wanting } \\
\text { (affection) }\end{array}$} & $\begin{array}{c}\text { Perceiving } \\
\text { (seeing, hearing) }\end{array}$ \\
\hline Know & Decide & Like & See \\
Reflect & Consider & Hate & Taste \\
Comprehend & Recall & Dislike & Hear, \\
Believe & Hypothesise & Want & Smell \\
Imagine & Wonder & Wish & Observe \\
Forget & Understand & Need & Notice \\
Remember & Assume & Fear & sense \\
Recollect & Recognise & Enjoy & \\
realise & Infer & & \\
\hline
\end{tabular}

Mental process, as stated by Eggin (1994: 242 in Emilia, 2014: 154) must have two participants: a senser, that is realised by a human or consciuous participant and a phenomenon, realised by a nominal group or embedded clause summing up what is thought, wanted, perceived or liked/ disliked as it is seen below taken from Emilia $(2014,154)$.

\begin{tabular}{lll}
\hline The higher middle class & will perhaps not feel & any meaningful effect \\
\hline senser & Process: affection & phenomenon \\
\hline & & \\
\hline English & should be taught & in all levels of education \\
\hline Goal & Process: material & Circumstance: Loc: Place \\
\hline
\end{tabular}

Nonetheless, mental process can sometimes have only one participant, that is in the situation when they project as in the following example. 


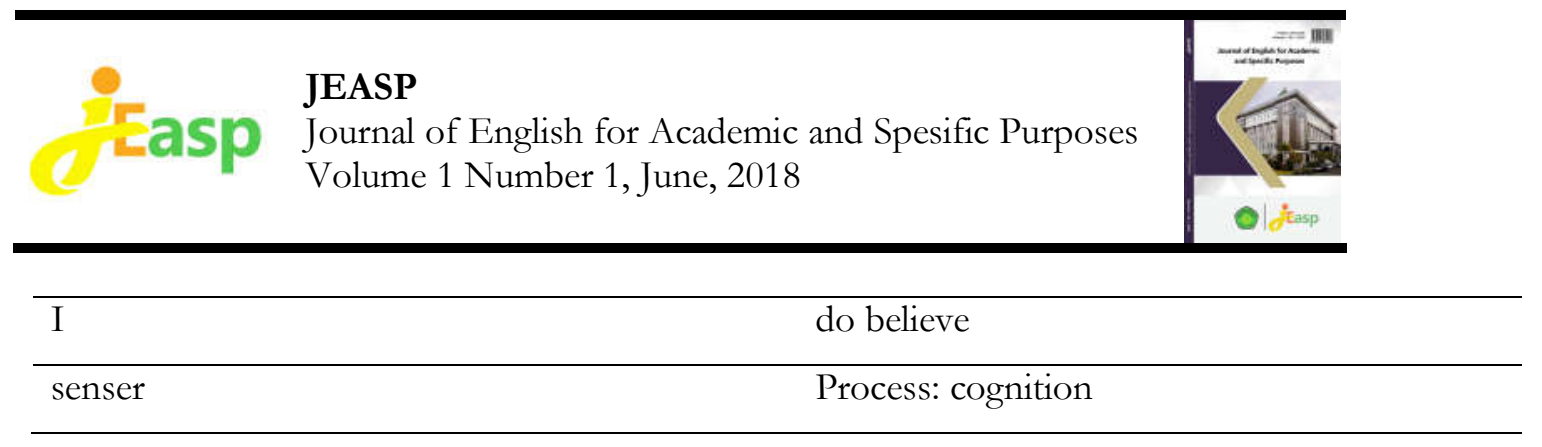

Sensing processes can refer to actions of perception as those-actioninvole the use of human senses: seeing, hearing, tasting, and smelling (Derewianka, 2011: 23 in Emilia, 2014: 154-155).

Verbal Processes: process of saying, (Halliday, 1994a in Emilia, 2014: 156) is described as whay did you say. However, the category of saying covers any kind of symbolic exchange of meaning, not only the different modes of saying (asking, stating, arguing) but also semiotic processes that are not necessarily verbal (showing, indicating) (Martin, Matthiesen, \& Painter, 1997: 108 in Emilia, 2014: 156). Participants roles of verbal processes is classified into : (i) a sayer, the participant responsible for the verbal process; (ii) a receiver: the one to whom the saying is addressed or directed; it may be the Subject in the passive clause; (iii) a Verbiage: the function that corresponds to what is said. As Emilia (2014: 156) has shown in the examples below.

\begin{tabular}{llll}
\hline We & can introduce & our own country & $\begin{array}{l}\text { to the world } \\
\text { community }\end{array}$ \\
\hline Sayer & Process: verbal & Verbiage & Receiver \\
\hline The teacher & Introduced & Jayden & to all students \\
\hline Sayer & Process: verbal & Target & Receiver \\
\hline
\end{tabular}

Another processes is relational processes: processes of being. Relational processes are processes of being (Halliday, 1994a: 119 in Emilia, 2014: 158). In English, according to Halliday, relational processes operates with main types such as (1) Intensive "x is a", (2) Circumstantial "is at a" (where is at" stands for "is at, in, on, for, with, about, along, etc), and (3) Possessive "x has a". Each type, halliday says, comes in two distinct modes: a. Attribute "a in an attributive of x", b. 
JEASP

Journal of English for Academic and Spesific Purposes

Volume 1 Number 1, June, 2018

Identifying " $\mathrm{a}$ is the identity of $\mathrm{x}$ ". Henceforth, there are six categories of relational processes, and these can be seen below.
(i) attributive
(ii) identifying

Mode

Type

(i) intensive Arie is smart Adam is the smartest

students.

The smartest students is

Adam.

(ii) circumstantial The fair is on a Tuesday Tomorrow is the 10th. T

he 10 th is tomorrow.

(iii) possessive $\quad$ Bobby has a piano The red book is Ika's.

Ika's is the red book.

The table above (adopted from Halliday, 1994a: 119 in Emilia, 2014: 158) shows one important difference between the attributive and the identifying modes. The attributive ones are not reversible: there is no form: smart is Arie, which is systematically related to "Arie is smart". However, the identifying ones ereversible, so that $\mathrm{x}$ and the a can be switched around " Arie is the smartest students/ the smartest students is Arie." Therefore, the relational clauses construe being and do this in two different modes: attribution and identification (Martin, Matthiessen, \& Painter, 1997: 106; Halliday, 1994a in Emilia, 2014: 159). Relational attributive relates a participant to its general characteristics or description, and relational identifying relates a participant to its identity, role or meaning. An identifying clause is not about ascribing or classifying, but defining, with the meaning being " $\mathrm{x}$ serves to define the identty of y" (Eggin, 1994: 258; see also Halliday, 1994a in Emilia,m 2014: 159).

Relational clauses (Emilia, 2014: 159) can be realised in different forms of be, and linking verbs. Attributive relational clauses where an entity has some quality attributed to it, and the quality is labelled 'the ATTRIBUTE and the entity to which it is ascribed is the CARRIER. 


\begin{tabular}{lll}
\hline Denny & is & diligent \\
\hline Sandra and Peter & Are & $\begin{array}{l}\text { students of English Letter } \\
\text { of UIN }\end{array}$ \\
\hline The story & Sounds & interesting \\
\hline Asis & Is & a hardworking person \\
\hline Achmad & has turned & into a wise man \\
\hline Whales & Are & mammals \\
\hline (iii)Carrier & Processes: Intensive & Attribute \\
\hline
\end{tabular}

Table: Adopted from Emilia (2014: 159)

There are four characteristics of attributive clauses which distinguish them from identifying ones (Halliday, 1994a: 120 in Emilia, 2014: 159-160): (i) the nomial group that functions as Attributive is typically indefinite. It has either an adjective or a common noun as Head and. If appropriate, an indefinite article (e.g. is/ are wise, is a poet, are poets, is a student, are students, is a teacher, are lecturers). It cannot be a proper noun or pronoun. (ii) the verb realises the process is one of the "ascriptive", classes; [phase: inceptive] become, turn into, grow into, get, go; [phase: durative] reamin, stay (as); keep; [phase, appearance] seem, appear, qualify as, turn out, end up (as); [phase, sense-perception] look, sound, smell, feel, taste (like); [neutral] be, feel; (iii) the probe for such clauses is what?, how?, or what...like?, for example: what is Ali?, How did Denny seem?, How did the Head of the Department seem?, What will the students be like? What will the result of the exam be like? , (iv) these clauses are not reversible: there is no forms such as: Interesting sounds the story.

Behavioural Processes: Processes of behaviour are processes of psychological or psychological behaviour (Halliday, 1994:139; Butt, et al, 2000: 54 in Emilia, 2014: 165) like breathing, dreaming, snoring, smiling, hiccuping, looking, watching, listening, and pondering or thinking carefully. Example of behaviourial processes can be seen below Emilia (2014: 165). 


\begin{tabular}{ll}
\hline JEASP & \begin{tabular}{l} 
Journal of English for Academic and Spesific Purposes \\
Volume 1 Number 1, June, 2018 \\
\hline You
\end{tabular} \\
\hline She & are daydreaming! \\
\hline Aziz & is not listening \\
\hline All students & is smiling \\
\hline Behaver & are always laughing \\
\hline
\end{tabular}

Existential Processes: Processes of existence represents experience by positing that "there was/ is something" (Eggins, 1994: 254 in Emilia, 2014: 166) "something exists or happens" it involves "there" and typically employ the verb to be or synonyms such as exist, arise, occur. The word "there" in such clauses is neither a participant nor circumstance-it has no representational function in the transitivity structure of the clause, but it serves to indicate the feature of existence, and it is needed interpersonally as a subject of the verb (Halliday \& Matthiessen, 2004: 257 in Emilia, 2014: 166).

\section{IMPLEMENTING ENGLISH LANGUAGE LEARNING FOR ESP CLASS}

This can be started by introducing students about the text of English language learning as a part of communication. It later can lead to understanding discourse as both, communication and discourse, are the core or relevant definitions of getting communicated through language (Fiske, 1990, p. 2 cited in Thompson, 2003 , p. 10). Communication is used in a number of sense and levels to indicate the transmission of information or even, as in the transport networks example, the transmissions of goods, things and poeple (Thompson, 2003, p. 10). This can be referred to anything that can be 'read' for meaning can be thought of as being a manifestation of one or more discourses and can be said as a 'text' (Burr, 1995 as cited in Thompson, 2003, p. 103). Meaning emerges from interactions and is closely related or linked to the idea of the context in which communication takes place. Therefore, text is something that cannot be separated or isolated from communication and discourse. They are joined to make text meaningful so that it can be developed into communicative competence as well as discourse competence. 
These two competences can include the students' background knowledge of understanding their field of subject as it can be related to the English language learning. This background knowledge can also be described into the three features, based on Halliday's three features of the context of situation (Halliday \& Hasan, 1985, p. 12) that can serve to interpret the social context of text, or situational description of text. These three headings can enable teacher and students to understand the nature of the text that is related to any specific purposes of field study and English language learning.

Below is the example of situational description of language, context and text from Financial Times, world business newspaper. 


\section{JEASP}

Journal of English for Academic and Spesific Purposes

Volume 1 Number 1, June, 2018

TEXT 1.1:

\section{SELLING DREAMS}

By John Munch

Ferrari, Italy's maker sports and racing cars, is among the three most recognizable brands in the world. The company got its high profile among the world's corporate giants without the help, for most of its existence, of an advertising department. Only as recently as 1993 did Ferrari create a marketing department. "Just parking our exciting automobiles is enough to draw the crowds" writes Gian Luigi Longinotti-Buitoni the author of a book called Selling Dreams.

Customers are now spending more money on products they desire rather than on products they simply need. All companies must therefore produce goods of very high quality more importantly, they must establish a brand for years to come by giving it emotional qualities that match customers' strongest desires. Like Ferrari, all companies must create and sell dreams'. LonginottiBuitoni gives some interesting statistics about markets for luxury goods worldwide: Switzerland with 220 Ferraris sold in 1997 is the largest market per capita for the car maker's products; the company, on the other hand, sells only $2,7 \%$ of its cars to women. Rolex and the highest number of luxury watches are sold in Italy, while Japan has been consistently the leading market in the world for leather goods from Gucci, Ferragamo, Hermes and Louis Vuitton. China amazingly, appears to be drinking a lot of Hennessy cognac.

From the http://www.ft.com/

FINANCIAL TIMES

World business newspaper (taken from Market Leader, 2004)

Situational description based on Halliday \& Hasan (1985, p. 12):

a. The Field: Through the article above can be referred to what is the news about or what is happening, to the nature of the social action takes place from the news article, in this example, it shows that the topic or theme is linked to the filed of study of marketing management.

b. The Tenor of discourse, based on the above article can refer to the writer, the reader, all the actors or participants who are taking part to the nature of participants, their role in the marketing management. This also shows the relationship obtain among the participants, including permanent and temporary relationship of one kind to another, that is, the writer and readers, as well as the actors take place in the article. 
c. The Mode of discourse can be referred to what part of the communication is used, it is clear that this article is in the written form. The writing form is playing in terms of what is the participants are expecting to do for the situation: the symbolic organization of the text, in this context, it is aimed at sharing information of the news item and the rhetorical mode of this can be said to have giving it emotional qualities that match the readers' strongest desires.

Text 1.1 was an article taken from financial times of world business newspaper can be used when someone reading an article, that is, of course, is related to the real world experienced by both writer ad readers. The headings of field, tenor, and mode can give the readers, or specifically, students, a characterisation of the nature of this kind of a text. Students can do similar texts in any kind of text; however it can also be used the same general ideas when it comes or is followed with the questions based on the text. By doing the exercise based the three headings of field, tenor, and mode, students and the teacher as the facilitator, are actually implementing the functional grammar.

\section{CONCLUSIONS}

Once the three headings of field, tenor, and mode are practised and implemented can result as the process of contextualisation in learning English language in ESP class. In order to understand text, teacher and students or learners in general have to have context. Texts are built up by the text as a metafunctional construct: a complex of ideational, interpersonal and textual meanings, the context of situation, and the content of culture. As a result, the context of situation of the text aims to represent the social function of any related field of subject within the frame of study. The understanding of context can help ESP students to make predictions about the meaning that are being exchanged through the process of communication within ESP class. 


\section{REFERENCES}

Emilia, E. (2014). Introducing Functional Grammar. Bandung: PT DUNIA PUSTAKA JAYA. Halliday, M.A.K \& Hasan Quqaiya. (1985). Language, Context, and Text: Aspect of language in a social-semiotic perspective. Victoria: Deakin University

Fiorito, L. (2005). http:/ /www.usingenglish.com/articles/teaching ESP.

Suyanto, Kasihani K.E. \& Octaberlina L.R. 2011. "The Teaching Techniques to Encourage Students to Speak." Paper presented at the School of Humanity and Culture of UIN Malang.

Thompson, Neil. (2003). Communication and Language: A handbook of theory and practice. New York: Palgrave MacMillian. http://www.usingenglish.com/web/pbl/whatis.htm 